\title{
LVIII. On sharks
}

\section{William Tatham Esq.}

To cite this article: William Tatham Esq. (1804) LVIII. On sharks, Philosophical Magazine Series

1, 17:68, 317-318, DOI: $10.1080 / 14786440408676425$

To link to this article: http://dx.doi.org/10.1080/14786440408676425

$$
\text { 曲 Published online: } 18 \text { May } 2009 .
$$

Submit your article to this journal

LII Article views: 2

Q View related articles $\asymp$ 


\title{
$[317]$
}

\section{On Sharks. By William Tatham, Esq.}

\author{
sir, \\ To Mr. Tilloch.
}

$O_{\text {BS }}$

BSERVING in a shop window a print representing an accident which happened from the voracity of a shark in the harbour of Havannah, in the island of Cuba; and having frequently noticed the propensity of the vulgar to swallow extraordinary instances as matters of general existence (believing all the western hemisphere to be overrun with monsters and savages, because geographers have, in some instances, thought fit to ornament their productions with Indians, bears, and snakes, with hideous creatures and wild ferocity); it may not be unpleasant to communicate to you a fact or two, within my own knowledge, touching the scene of action in this print, which may not happen to be readily obtained from any other quarter.

In the year 1793 I was on board the Philadelphia ship Carolina, which was several weeks at anchor in the very spot which this print exhilits; and I have been at the bottom in the place where this accident happencd : it is composed of a blue or greenish clay, indented with small holes as if made with the fingers, which I am inclined to think is the work of small fishes, wherewith the harbour abounds; and the clay is covered with a thin film, or skin, not unlike brown paper. The water (probably from the shade of the scivannas adjoining) has a grecnish appearance, and is replete with a small species of worm, or maggot, similar to the skippers in rotten cheese. I understood, however, that it is not this but another species of worm which renders it necessary to copper the bottoms of the ships; nor do the Spaniards ascribe to them any species of depredation, although the surface of the harbour at some times exhibits them as a kind of cream on the bason's contents. This subject may nevertheless merit the investigation of ship owners; and it may also deserve consideration how far chemical knowledge may be directed to the discovery of some cheap substitute for copper, which may be more generally applied to ships in the merchant service, thereby economizing the consumption of a material which constitutes the basis of a considerable portion of British manufacture and commerce.

I beg leave to state, in regard to the case of the shark, that it is by no means my intention to encourage further experiments at the bottom of the harbour of the Havannah: on the contrary, I observed the Spaniards frequently bathing near the shores, but never in the deep water, where the crew 
of the Carolina were accustomed to jump overboard. I merely state this fact, to distinguish a casual from an unavoidable case, and to show that all dangers are not death, no more than it should be conceived necessary that travellers should be always killed in the Sierra Movena, or in Cumberland Mountain in America, because such accidents have been frequent antecedent to the period when civiliza. tion conquered the wilderness.

Not being acquainted with the natural history of fishes, I can only merely state another fact concerning sharks. In the harbour of Charleston, in South Carolina, I was astonished to see a boy fall from a ship's bowsprit into the water, without injury, where two or three sharks were playing about the ship a few minutes before; but I was still more so, at seeing two sharks playing about in the surf where a parcel of children were bathing in shallow water, who seemed to be noways concerned for their safety. On expressing my anxiety, and warning the children of their apparent danger, some of the inhabitants who stood on the beach laughed, and assured me that those two sharks were old playmates of the children, who were well acquainted with them; for that they had long frequented the place, and were not of a ravenous species; and that if one of the dangerous kind came in the way I should soon see the children scamper, as they were perfectly acquainted with the diference between the two. If you deem these facts worth public notice, you are at liberty to publish them, on the authority of, Sir, your humble servant,

December 3, 1803 .

William Tatham.

LIX. On Vegetation; extracted from C. Hassenfratz's Paper on that Sulject. By G. J. Wright, Esq.

$$
\text { sin, To Mr. Tilloch. }
$$

$T_{\text {He fragment I enclose for your insertion is extracted }}$ from a memoir of Cit. Hassenfratz on vegetation *, a paper of some import, and frequently quoted by philosophical men, though not, that $I$ have been able to find, inserted in any English publication. Innagining the subject of experiment of so respectable a philosopher would not be regarded as superfluous by your readers, I have in my leisure hours (and owing to the want of original matter, through the te-

* Annales de Chimie, sone xiii. and xiv.

diousness 